\title{
A bacteriophage-like particle from Bartonella bacilliformis
}

\author{
Kent D. Barbian and Michael F. Minnick
}

Division of Biological Sciences, The University of Montana, Missoula, MT 59812-4824, USA
Author for correspondence: Michael F. Minnick. Tel: +1 406243 5972. Fax: +1 4062434184. e-mail:minnick@selway.umt.edu

Bartonella bacilliformis and Bartonella henselae, the respective agents of Oroya fever and cat-scratch disease in humans, are known to produce bacteriophage-like particles (BLPs) that package $14 \mathrm{kbp}$ segments of the host chromosome. Data from this study suggest that other Bartonella species including Bartonella quintana, Bartonella doshiae and Bartonella grahamii also contain similar BLPs, as evidenced by the presence of a $14 \mathrm{kbp}$ extrachromosomal DNA element in their genomes, whereas Bartonella elizabethae and Bartonella clarridgeiae do not. A purification scheme utilizing chloroform, DNase I and centrifugation was devised to isolate BLPs from B. bacilliformis. Intact BLPs were observed by transmission electron microscopy and were round to icosahedral in shape and approximately $80 \mathrm{~nm}$ in diameter. RFLP and Southern blot analysis of BLP DNA from B. bacilliformis suggest that packaging, while non-selective, is less than the near-random packaging previously reported for the $B$. henselae phage. Data also suggest that the linear, double-stranded BLP DNA molecules have blunt ends with noncovalently closed termini. Packaging of the BLP DNA molecules into a protein coat appears to be closely related to nucleic acid synthesis, as unpackaged phage DNA is not detectable within the host cell. SDS-PAGE analysis of purified BLPs from B. bacilliformis showed three major proteins with apparent molecular masses of 32,34 and $36 \mathrm{kDa}$; values that closely correspond to proteins found in $B$. henselae BLPs. Western blot analysis performed with patient convalescent serum showed that BLP proteins are slightly immunogenic in humans. To determine if BLPs contribute to horizontal gene transfer, mutants of $B$. bacilliformis were generated by allelic exchange with an internal fragment of the 16S-23S rDNA intergenic spacer region and a suicide vector construct, termed pKB1. BLPs from one of the resultant strains were able to package the mutagenized region containing the kanamycinresistance cassette; however, numerous approaches and attempts at intraspecies transduction using these BLPs were unsuccessful.

Keywords: Bartonella, bacteriophage, defective phage, transduction

\section{INTRODUCTION}

Bartonella bacilliformis is a Gram-negative, haemotrophic bacterium (Kreier \& Ristic, 1981) that is capable of invading and replicating inside human erythrocytes and endothelial cells (Benson et al., 1986; McGinnis-Hill et al., 1992). The pathogen is transmitted to humans by

Abbreviations: BLP, bacteriophage-like particle; Cam, chloramphenicol; Kan, kanamycin. the bite of a female sandfly (Lutzomyia spp.) (Hertig, 1942). The resulting infection manifests as a biphasic disease. The primary, or haematic phase, is characterized by fever, malaise, skin pallor and a severe haemolytic anaemia where nearly all of the circulating erythrocytes are infected (Reynafarje \& Ramos, 1961) and nearly $80 \%$ are lysed (Hurtado et al., 1938). Four to eight weeks following the haematic phase, patients generally proceed to a secondary, or tissue, phase in which the bacterium invades vascular endothelial cells (McGinnis-Hill et al., 1992). This phase is characterized 
by localized cutaneous eruptions, or haemangiomas, on the face and extremities and is termed verruga peruana (Garcia-Caceres \& Garcia, 1991). The mechanisms by which $B$. bacilliformis gains entry into erythrocytes and endothelial cells, as well as additional virulence determinants, are being investigated (for a recent review, see Minnick, 1997).

Previous work showed that Bartonella henselae, an agent of cat-scratch disease and bacillary angiomatosis, produces bacteriophage-like particles (BLPs) that package random, $14 \mathrm{kbp}$ fragments of Bartonella DNA (Anderson et al., 1994). The heterogeneous mixture of double-stranded host DNA contained in the B. henselae BLPs is protected from chloroform/DNase I treatments by capsid proteins (Anderson et al., 1994; Bowers et al., 1998). Furthermore, BLPs are non-lytic even when the host cell is subjected to UV irradiation and/or the addition of mitomycin C. Little more is known about Bartonella BLPs or the mechanisms by which the DNA is packaged, although similarities with generalized defective phages suggest that headful packaging into a pre-formed capsid head may be taking place (Yarmolinsky \& Sternberg, 1988; Birge, 1994).

Defective phages are unique when compared to true bacteriophages. Although they share some properties that are similar to true phages, most defective phages package host DNA into pre-formed capsid heads and do not contain any apparent genomic material from the phage (Garro \& Marmur, 1970). Defective phages have been found in a variety of unrelated bacteria including the Bacillus subtilis PBSX phage (Yarmolinsky \& Sternberg, 1988; Birge, 1994) and the Serpulina byodysenteriae VSH-1 phage (Humphrey et al., 1997), the latter of which has been shown to undergo generalized transduction. The purpose of this study was to characterize the molecular biology of the B. bacilliformis BLPs and begin to address our hypothesis that Bartonella BLPs participate in intraspecies (and possibly interspecies) horizontal gene transfer via transduction.

\section{METHODS}

Growth of bacterial strains. Bacterial species and strains used in this study are summarized in Table 1 . B. bacilliformis strains were grown for $3-4 \mathrm{~d}$ at $30^{\circ} \mathrm{C}$ in a water-saturated atmosphere on heart infusion agar-blood (HIAB), which consists of heart infusion agar plates (Difco) supplemented with $4 \%(\mathrm{v} / \mathrm{v})$ defibrinated sheep erythrocytes and $2 \%(\mathrm{v} / \mathrm{v})$ filter-sterilized sheep serum (Quad Five). Other Bartonella species were similarly cultured, but at $37{ }^{\circ} \mathrm{C}$ with $5 \% \mathrm{CO}_{2}$. Escherichia coli strains were grown overnight at $37^{\circ} \mathrm{C}$ in Luria-Bertani medium with standard antibiotic supplements when required (Davis et al., 1980). The antibiotic supplements used in this study included $25 \mu \mathrm{g}$ kanamycin (Kan) $\mathrm{ml}^{-1}$ and $2 \mu \mathrm{g}$ chloramphenicol (Cam) $\mathrm{ml}^{-1}$ (Sigma) and were used individually or combined depending upon experimental conditions.

Purification of BLPs. BLPs were prepared by inoculating $B$. bacilliformis strains onto HIAB. Approximately 40 plates were harvested into $15 \mathrm{ml} \mathrm{SM}$ phage buffer (Ausubel et al., 1995). Chloroform $(3 \%, v / v)$ was used to lyse the bacterial cells, and cellular debris was subsequently removed by centrifuging for $5 \mathrm{~min}$ at $6000 \mathrm{~g}$. The supernatant was collected, chloroform-treated again, and centrifuged a second time. DNase I was added to the resulting supernatant to a final concentration of $2 \mu \mathrm{g} \mathrm{ml} \mathrm{m}^{-1}$, and incubated at $37^{\circ} \mathrm{C}$ for $2 \mathrm{~h}$ to digest chromosomal DNA. The BLPs were then pelleted by ultracentrifugation for $2 \mathrm{~h}$ at $100000 \mathrm{~g}$ in a SW60 rotor (Beckman), using a $15 \%$ sucrose cushion. The supernatant was discarded and the pellets were resuspended in $150 \mu \mathrm{l}$ fresh $\mathrm{SM}$ buffer and stored at $4{ }^{\circ} \mathrm{C}$ until needed.

Preparation and manipulation of DNA. Nucleic acids for DNA hybridization or PCR were extracted from bacteria or BLP suspensions using a CTAB technique (cetyltrimethylammonium bromide) as described by Ausubel et al. (1995). Plasmids were extracted by either an alkaline lysis procedure (Birnboim \& Doly, 1979), or a Qiagen Midi Prep kit as per the manufacturer's instructions. Restriction digestion, ligation, denaturation/renaturation (using $0.2 \mathrm{M} \mathrm{NaOH}$ and $2 \mathrm{M}$ Tris $/ \mathrm{HCl}, \mathrm{pH} 8 \cdot 0$ ) and transformation of DNA fragments into E. coli $\mathrm{DH} 5 \alpha$ were carried out using standard protocols (Ausubel et al., 1995). DNA fragments for cloning or hybridization were extracted from ethidium-bromide-stained agarose gels by a GeneClean kit (Bio 101). Plasmids used or generated in this report are summarized in Table 1.

Agarose gel electrophoresis and Southern blot analysis. DNA was separated via electrophoresis through $0 \cdot 8 \%(\mathrm{w} / \mathrm{v})$ agarose gels containing ethidium bromide. DNA in the gel was transferred to nitrocellulose membranes $(0.45 \mu \mathrm{m}$ pore size; Schleicher \& Schuell) by the method of Southern (1975) and subsequently baked for $1 \mathrm{~h}$ at $80^{\circ} \mathrm{C}$ to fix the DNA. DNA probes were labelled by random primer extension with Klenow (Gibco-BRL) and $\left[\alpha^{32} \mathrm{P}\right] \mathrm{dCTP}$ (New England Nuclear). Nitrocellulose blots were probed overnight at $60^{\circ} \mathrm{C}$, washed at high stringency (approx. 7\% mismatch), and developed as previously described (Minnick et al., 1990).

SDS-PAGE and immunoblotting. BLP proteins were resolved by electrophoresis through SDS-polyacrylamide $(12.5 \%, \mathrm{w} / \mathrm{v}$, acrylamide) gels using methods adapted from Laemmli (1970). The gels were then stained with Coomassie brilliant blue to visualize protein bands. For immunoblots, separated proteins were transferred from gels to nitrocellulose membranes $(0 \cdot 45 \mu \mathrm{m}$ pore size) via electrophoresis (Towbin et al., 1979). Western blots were developed as previously described (Scherer et al., 1993).

Transmission electron microscopy. Bacterial cells and/or purified BLPs were resuspended in $10 \%$ (v/v) glycerol/water. Suspensions were prepared for negative-stain electron microscopy on Silicon Monoxide Type-A support grids (300 mesh copper). Samples were allowed to electrostatically attach to the grids for $5 \mathrm{~min}$. Excess liquid was subsequently blotted away and the grids were allowed to air dry for $2 \mathrm{~min}$. Grids were then stained for $3 \mathrm{~min}$ with $2 \%$ filter-sterile uranyl acetate $(\mathrm{pH} 7 \cdot 0)$. After destaining with $1 \mathrm{M}$ ammonium acetate ( $\mathrm{pH} 7 \cdot 0$ ) for 4 min and washing with deionized $\mathrm{H}_{2} \mathrm{O}$ for $1 \mathrm{~min}$, the grids were air-dried and examined at $75 \mathrm{kV}$ with a Hitachi 7100 transmission electron microscope.

Generation of $\operatorname{Kan}^{R}$ B. bacilliformis mutants. Kan ${ }^{R}$ mutants were generated via allelic exchange with a suicide vector, termed pKB1. pKB1 was constructed by cloning a $1.3 \mathrm{kbp}$ BamHI-SalI fragment from pKRT3 containing the 16S-23S rDNA ITS region from $B$. bacilliformis into pUB1. After construction of pKB1, the plasmid was electroporated into $B$. bacilliformis JB584 as previously described by Battisti \& Minnick (1999) and allowed to homologously recombine with 
Table 1. Bacterial strains and plasmids

\begin{tabular}{|c|c|c|}
\hline Strain/plasmid & Description & Reference \\
\hline \multicolumn{3}{|l|}{ Strains } \\
\hline \multicolumn{3}{|l|}{ E. coli } \\
\hline $\mathrm{DH} 5 \alpha$ & $\begin{array}{l}\text { Host for cloning and plasmid } \\
\text { propagation }\end{array}$ & Gibco-BRL \\
\hline \multicolumn{3}{|l|}{ Bartonella } \\
\hline B. bacilliformis KC583 & Neotype strain & Brenner et al. (1991) \\
\hline B. bacilliformis KC584 & Peruvian isolate, 1963 & Brenner et al. (1991) \\
\hline B. bacilliformis JB584 & $\begin{array}{l}\text { HG584 cured of pEST }\left(\operatorname{Kan}^{\mathrm{s}}\right. \\
\left.\text { Cam }^{\mathrm{s}}\right)\end{array}$ & Battisti \& Minnick (1999) \\
\hline B. bacilliformis JB585 & $\begin{array}{l}\text { fla mutant of JB584 }\left(\mathrm{Kan}^{\mathrm{R}}\right. \\
\left.\mathrm{Cam}^{\mathrm{s}} \text { fla }\right)\end{array}$ & Battisti \& Minnick (1999) \\
\hline B. bacilliformis $\mathrm{KB} 484$ & $\begin{array}{l}\text { JB584 containing pBBR1MCS } \\
\left(\operatorname{Kan}^{\mathrm{S}} \mathrm{Cam}^{\mathrm{R}}\right)\end{array}$ & This study \\
\hline B. bacilliformis KB584 & $\begin{array}{l}\text { One of three } 16 \mathrm{~S}-23 \mathrm{~S} \text { ITS } \\
\text { regions of JB584 interrupted } \\
\text { by insertion of pKB1 (Kan } \\
\left.\text { Cam }^{\mathrm{S}}\right)\end{array}$ & This study \\
\hline B. bacilliformis KB585 & $\begin{array}{l}\text { One of three 16S-23S ITS } \\
\text { regions of JB584 interrupted } \\
\text { by insertion of pKB1 }\left(\mathrm{Kan}^{\mathrm{R}}\right. \\
\left.\mathrm{Cam}^{\mathrm{S}}\right)\end{array}$ & This study \\
\hline B. bacilliformis $\mathrm{KB} 686$ & $\begin{array}{l}\text { Spontaneous Cam }{ }^{\mathrm{R}} \text { mutant of } \\
\operatorname{KB} 585\left(\operatorname{Kan}^{\mathrm{R}} \mathrm{Cam}^{\mathrm{R}}\right)\end{array}$ & This study \\
\hline B. clarridgeiae & $\begin{array}{l}\text { Isolate from cat with } \\
\text { septicaemia }\end{array}$ & Lawson \& Collins (1996) \\
\hline B. elizabethae & Human endocarditis isolate & Daly et al. (1993) \\
\hline B. doshiae R18 & Type strain & Birtles et al. (1995) \\
\hline B. grahamii V2 & Type strain & Birtles et al. (1995) \\
\hline B. henselae Houston R1302 & Type strain & Regnery et al. (1992) \\
\hline B. quintana Fuller & Type strain & Myers et al. (1979) \\
\hline B. vinsonii Baker & Vole agent & Weiss \& Dasch (1982) \\
\hline \multicolumn{3}{|l|}{ Plasmids } \\
\hline pKRT3 & $\begin{array}{l}\text { pUC19 containing } 1.8 \mathrm{kbp} \\
\text { BamHI fragment of the } \\
\text { 16S-23S ITS region from } \\
\text { B. bacilliformis }\end{array}$ & Minnick et al. (1994) \\
\hline pUB1 & $\begin{array}{l}\text { B. bacilliformis suicide vector } \\
\text { containing the } n p t I \text { gene } \\
\left(\mathrm{Kan}^{\mathrm{R}}\right)\end{array}$ & Battisti \& Minnick (1999) \\
\hline pKB1 & $\begin{array}{l}\text { pUB1 containing } 1.3 \mathrm{kbp} \\
\text { Bam HI-SalI fragment of the } \\
\text { 16S-23S ITS region from } \\
\text { pKRT3 }\left(\operatorname{Kan}^{\mathrm{R}}\right)\end{array}$ & This study \\
\hline pBBR1MCS & $\begin{array}{l}\text { B. bacilliformis shuttle vector } \\
\left(\mathrm{Cam}^{\mathrm{R}}\right)\end{array}$ & Kovach et al. (1994) \\
\hline pBBR1MCS-2 & $\begin{array}{l}\text { B. bacilliformis shuttle vector } \\
\left(\operatorname{Kan}^{\mathrm{R}}\right)\end{array}$ & Kovach et al. (1995) \\
\hline $\operatorname{lp} 16$ & $\begin{array}{l}\text { Linear plasmid from Borrelia } \\
\text { burgdorferi with covalently } \\
\text { closed ends }\end{array}$ & Barbour \& Garon (1987) \\
\hline
\end{tabular}

one of the three 16S-23S rDNA operons within the Bartonella chromosome. $\mathrm{Kan}^{\mathrm{R}}$ mutants were selected by plating the electroporated bacteria onto HIAB containing Kan. After
$12 \mathrm{~d}$, individual $\mathrm{Kan}^{\mathrm{R}}$ colonies were harvested, grown and analysed via PCR and Southern blot analysis to verify allelic exchange. 
Transduction experiments. Two plates of 2-d-old bacteria (KB484 and KB585) were harvested separately into $500 \mu \mathrm{l}$ heart infusion broth (HIB), enumerated by plate counts $\left(1-2 \times 10^{6}\right.$ cells $\left.\mathrm{ml}^{-1}\right)$, and plated onto HIAB containing Kan and Cam to control for spontaneous mutations to either antibiotic. The two strains were combined into $350 \mu \mathrm{l} \mathrm{HIB}$ from which three $100 \mu \mathrm{l}$ aliquots were plated onto HIAB to allow for interaction between the two strains. After $1 \mathrm{~d}$, the resulting growth was harvested into $350 \mu \mathrm{l} \mathrm{HIB}$ and dispensed onto HIAB containing Kan, Cam, or a combination of the two antibiotics. Similar platings were performed after 2 and $3 \mathrm{~d}$, respectively. After a $20 \mathrm{~d}$ incubation period, double antibioticresistant colonies were harvested, grown and characterized via Southern blot and PCR analysis.

In addition to co-incubating strains, purified BLPs from $\mathrm{Kan}^{\mathrm{R}}$ $B$. bacilliformis mutants were also used in transduction experiments. Briefly, two plates of 2-d-old B. bacilliformis (KB484) were harvested into $500 \mu \mathrm{l}$ sterile recovery broth. Bacteria were enumerated by plate counts to obtain approximate numbers being infected $\left(1-2 \times 10^{6}\right.$ cells $\left.\mathrm{ml}^{-1}\right)$. A $50 \mu \mathrm{l}$ aliquot of purified BLPs from $\mathrm{Kan}^{\mathrm{R}}$ B. bacilliformis mutants was then added to the harvested KB484 bacteria to yield an approximate m.o.i. of 10, and allowed to incubate at $30{ }^{\circ} \mathrm{C}$ for $1 \mathrm{~h}$. To prolong interaction under optimal conditions, three $100 \mu \mathrm{l}$ aliquots were plated onto HIAB for a period of 1-3 d. After the allotted time period, the resulting growth was harvested into $350 \mu \mathrm{l} \mathrm{HIB}$ and all subsequent actions were carried out exactly as stated above.

PCR analysis. PCR amplifications were done using a core kit and Taq polymerase (Perkin Elmer). Reactions were carried out as previously described (Minnick \& Barbian, 1997). Oligonucleotide primers specific for the Kan- and Camresistance cassettes as well as primers specific for the flagellin, gyrase $B$ and invasion associated locus $B$ genes of $B$. bacilliformis were synthesized by The University of Montana Murdock Molecular Biology Facility.

\section{RESULTS}

\section{BLP characteristics}

Extrachromosomal DNA in B. bacilliformis. When total DNA was prepared from various Bartonella species and analysed by agarose gel electrophoresis, a band migrating at $14 \mathrm{kbp}$ was observed in Bartonella henselae, Bartonella quintana, Bartonella doshiae, Bartonella grahamii and all strains of $B$. bacilliformis used in this study. However, Bartonella clarridgeiae, Bartonella elizabethae and Bartonella vinsonii did not contain a detectable extrachromosomal element. DNA isolated from B. bacilliformis (JB584) (the strain used for mutagenesis) clearly exhibited the $14 \mathrm{kbp}$ extrachromosomal element (Fig. 1, lane 2). This 14 kbp DNA fragment was always present in DNA preparations from $B$. bacilliformis and is the same size as reported for $B$. henselae BLP DNA (Anderson et al., 1994).

BLP ultrastructure. Transmission electron microscopy was performed to examine purified BLPs and BLPs in association with the $B$. bacilliformis cell. Particles of approximately $80 \mathrm{~nm}$ in diameter were found to exist freely as well as attached to the surface of the bacterium (Fig. 2a). The BLPs from B. bacilliformis appeared to be round to icosahedral; however, they were nearly twice

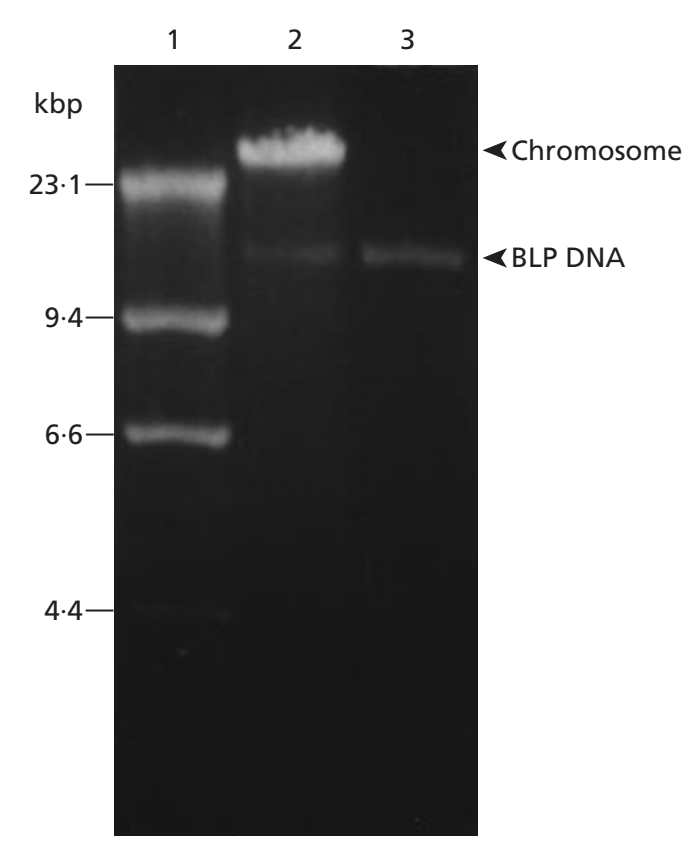

Fig. 1. Total DNA from $B$. bacilliformis (JB584) and analysis of BLP purity following the purification protocol described in the text. Lanes: $1, \lambda$-HindIII DNA as a molecular size standard; 2 , total DNA from $B$. bacilliformis (JB584) showing both chromosomal and BLP DNA; 3, DNA from purified BLPs showing a single DNA band at approximately $14 \mathrm{kbp}$.

the size reported for B. henselae BLPs (Anderson et al., 1994). Transmission electron microscopy showed that purified BLPs (Fig. 2b) were indistinguishable from those observed in association with B. bacilliformis (Fig. 2a). Although a previous report concerning the ultrastructure of the $B$. bacilliformis phage reported tail structures (Umemori et al., 1992), we never observed them. Likewise, tails were not found in BLPs from $B$. henselae (Anderson et al., 1994).

Nucleic acid extraction of the purified BLP preparation followed by agarose gel electrophoresis revealed a single band migrating at $14 \mathrm{kbp}$ (Fig. 1, lane 3), showing there is a direct correlation between the BLPs from $B$. bacilliformis and the $14 \mathrm{kbp}$ extrachromosomal element.

BLP nucleic acid. To begin to characterize the nucleic acid harboured by $B$. bacilliformis BLPs, nucleic acid from $B$. bacilliformis (JB584) was treated with RNase-free DNase I and subjected to agarose gel electrophoresis. DNase I sensitivity of the $14 \mathrm{kbp}$ element indicated that the BLP nucleic acid was DNA (e.g. see Fig. 5, lane 2). Furthermore, the BLP DNA was resistant to degradation if the particles were incubated with DNase I prior to nucleic acid extraction (e.g. see Fig. 5, lane 6), suggesting that a capsid or coat protects the enclosed DNA from degradation.

Isolated BLP DNA failed to renature when subjected to alkaline denaturation followed by rapid neutralization 

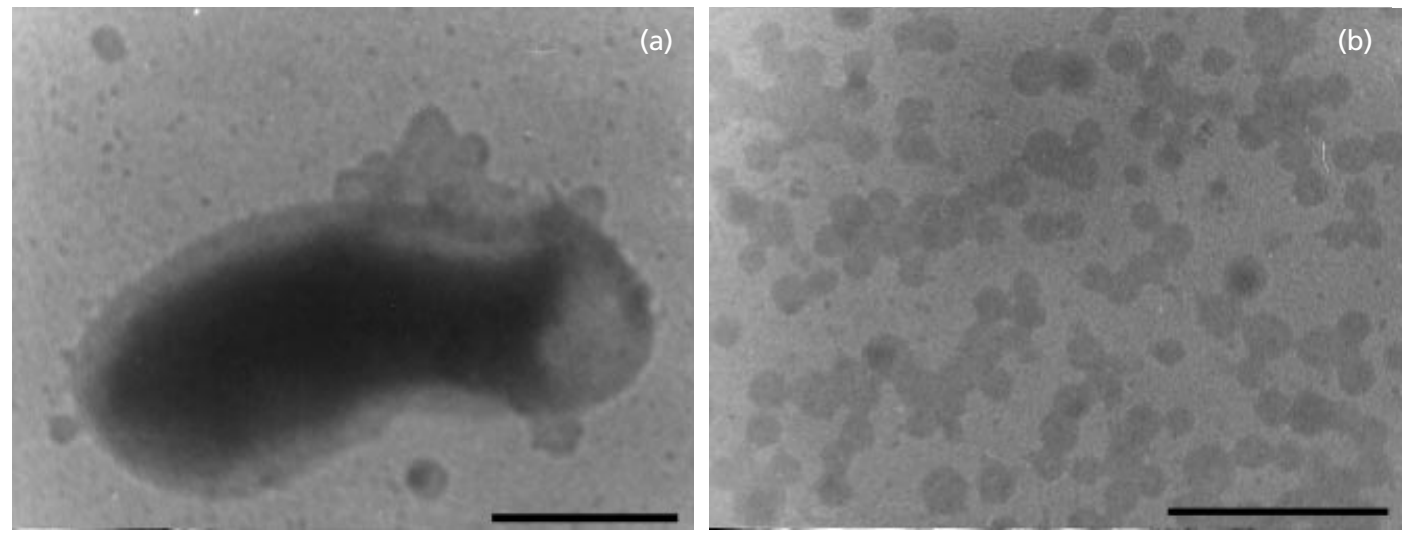

Fig. 2. Transmission electron micrographs showing $B$. bacilliformis BLP ultrastructure. (a) JB585 cells (Fla ${ }^{-}$to eliminate contaminating flagella) showing attached BLPs. (b) Purified BLPs prepared from JB585. Bars, $250 \mathrm{~nm}$.

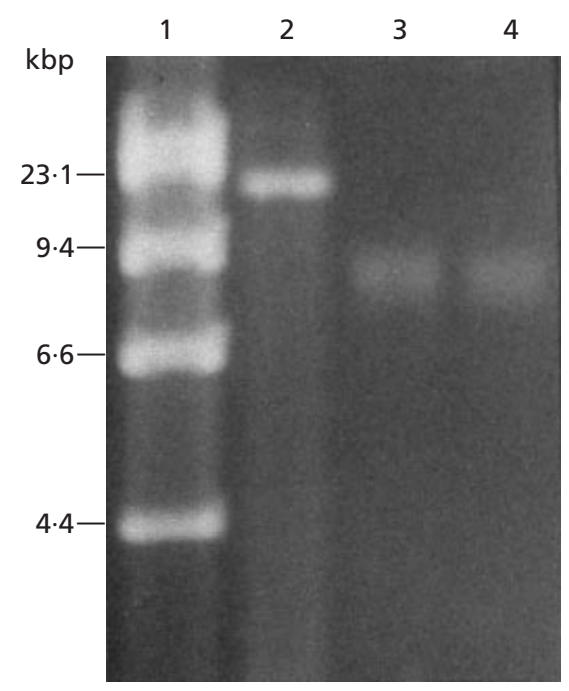

Fig. 3. Alkaline denaturation/renaturation analysis of BLP DNA on a $0.8 \%$ agarose gel showing that BLP DNA ends are not covalently closed. Lanes: $1, \lambda$-HindIII DNA as a molecular size standard; 2, untreated BLP DNA; 3, BLP DNA treated with an equal volume of $0.2 \mathrm{M} \mathrm{NaOH} ; 4$, BLP DNA treated with an equal volume of $0.2 \mathrm{M} \mathrm{NaOH}$ followed by rapid renaturation with $2 \mathrm{M}$ Tris/ $\mathrm{HCl}(\mathrm{pH} 8 \cdot 0)$.

(Fig. 3, lane 4). Identical treatment of lp16, a linear plasmid from Borrelia burgdorferi with covalently closed hairpin ends, showed rapid renaturation as did circular plasmid controls (data not shown). These results suggest that the BLP nucleic acid consists of a $14 \mathrm{kbp}$, linear, double-stranded DNA with non-covalently closed ends.

To further characterize the termini of the BLP DNA molecules, ligation experiments were performed using T4 DNA ligase. Ligation conditions favouring the joining of either cohesive ends ( $1 \mathrm{mM}$ ATP, $1 \mathrm{U}$ T4 DNA ligase) or blunt ends ( $0.5 \mathrm{mM}$ ATP, 20 U T4 DNA ligase) were employed to determine the nature of the BLP DNA termini. When the reaction mixture favoured cohesive-end ligation, no detectable ligation was ob- (a)

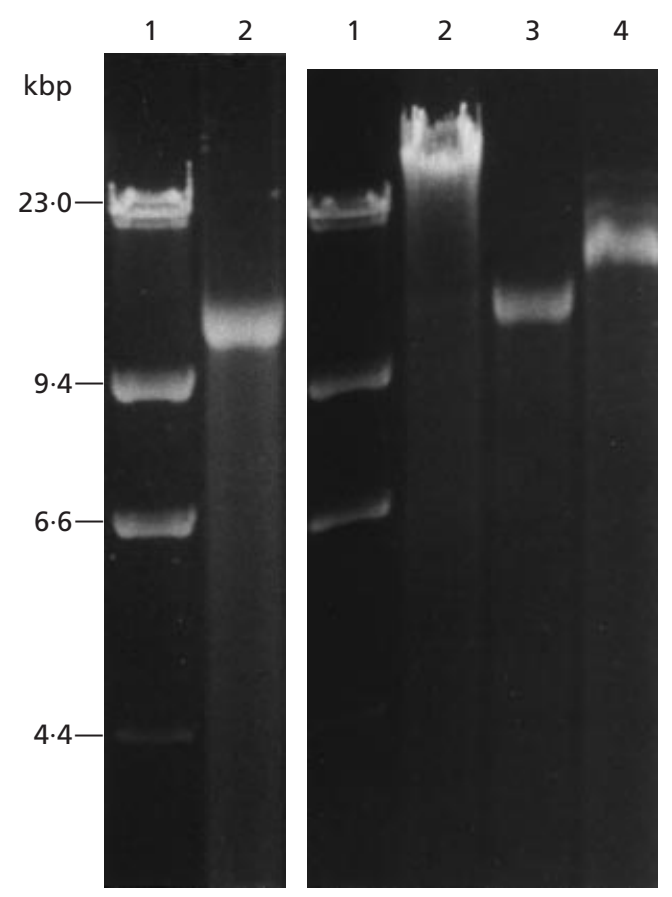

Fig. 4. Ligation analysis of BLP DNA on a $0.8 \%$ agarose gel showing that BLP DNA termini are blunt. (a) Ligation products produced when reaction conditions favour the ligation of cohesive ends (Ausubel et al., 1995). Lanes: $1, \lambda$-HindIII DNA as a molecular size standard; 2 , purified BLP DNA ligated with a low concentration of T4 DNA ligase (note the absence of ligation products). (b) Ligation products produced when reaction conditions favour the ligation of blunt ends (Ausubel et al., 1995). Lanes: 1, $\lambda$-HindllI DNA as a molecular size standard; 2 , total DNA from $B$. bacilliformis (JB584) showing both chromosomal and BLP DNA; 3, purified BLP DNA treated as in lane 4 but without T4 DNA ligase; 4, purified BLP DNA with a high concentration of T4 DNA ligase (note the presence of multiple ligation products).

served (Fig. 4a, lane 2). However, when the ligation reaction mixture favoured blunt-end ligation, ligation products were clearly visible (Fig. 4b, lane 4). Controls 


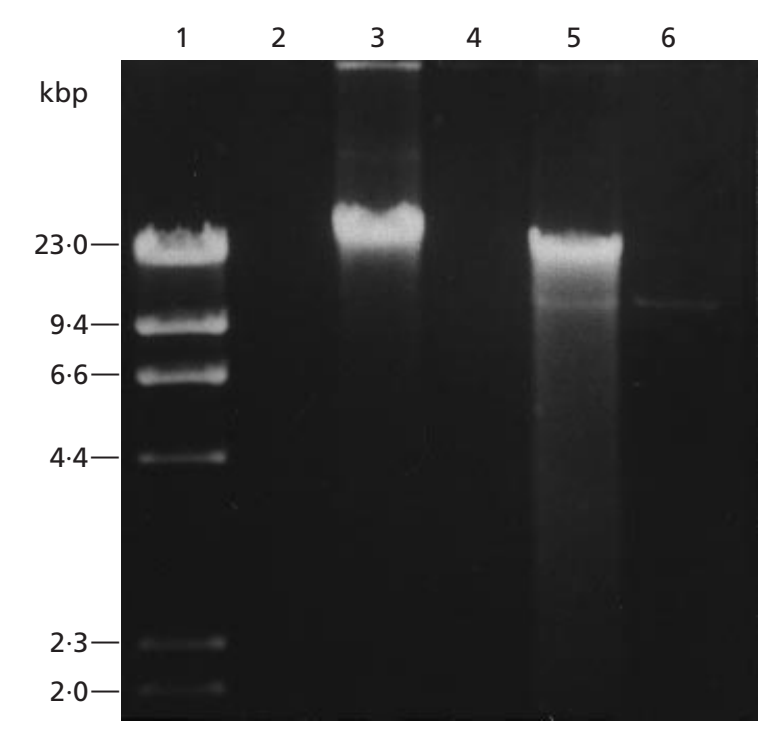

Fig. 5. A $0 \cdot 8 \%$ agarose gel showing that 'free' (unpackaged) BLP DNA molecules are not detectable within the $B$. bacilliformis cells. Lanes: $1, \lambda$-HindIII DNA as a molecular size standard; 2 , total DNA from $B$. bacilliformis (JB584) incubated with DNase I $\left(2 \mu \mathrm{g} \mathrm{ml}^{-1}\right)$; 3, DNA from B. bacilliformis (JB584) treated with $\mathrm{CHCl}_{3}$ (note the absence of the $14 \mathrm{kbp}$ BLP DNA band); 4, DNA from purified BLPs treated with $\mathrm{CHCl}_{3}$ (note the absence of $14 \mathrm{kbp}$ BLP DNA); 5, DNA from $B$. bacilliformis (JB584) treated with $10 \%$ SDS (note the presence of both chromosomal and BLP DNA); 6, DNA product when purified BLPs are incubated with DNase I $\left(2 \mu \mathrm{g} \mathrm{ml}^{-1}\right)$ and treated with $10 \%$ SDS immediately prior to electrophoresis.

for the ligation experiments included $\lambda$-HindIII DNA fragments (cohesive ends) and pUC19 linearized with EcoRV (blunt ends). Under conditions favouring cohesive-end ligation, products were only observed with $\lambda$ HindIII DNA fragments and not with pUC19 linearized with EcoRV (data not shown). Additionally, under conditions that favoured blunt-end ligation, products were observed with both controls (data not shown). Taken as a whole, these results suggest that the BLP DNA has blunt ends.

To determine if BLP DNA exists as a naked extrachromosomal element or if it is associated within a protein coat, chloroform $\left(\mathrm{CHCl}_{3}\right)$ treatment of $B$. bacilliformis followed by agarose gel electrophoresis analysis of the DNA was performed. Upon analysis, chromosomal DNA was clearly observed, but the $14 \mathrm{kbp}$ BLP DNA could not be detected. However, a band possibly representing unlysed BLPs could be detected in the base of the well (Fig. 5, lane 3). When an equal aliquot of bacteria was treated with SDS to lyse both bacteria and BLPs then analysed by agarose gel electrophoresis, both chromosomal DNA and the $14 \mathrm{kbp}$ BLP DNA were observed with concomitant loss of the band in the base of the well (Fig. 5, lane 5). These results suggest that, within the detection limits of ethidiumbromide staining, all BLP DNA is packaged in a protein coat and is protected from $\mathrm{CHCl}_{3}$ extraction. Additional experiments performed on purified BLPs showed that

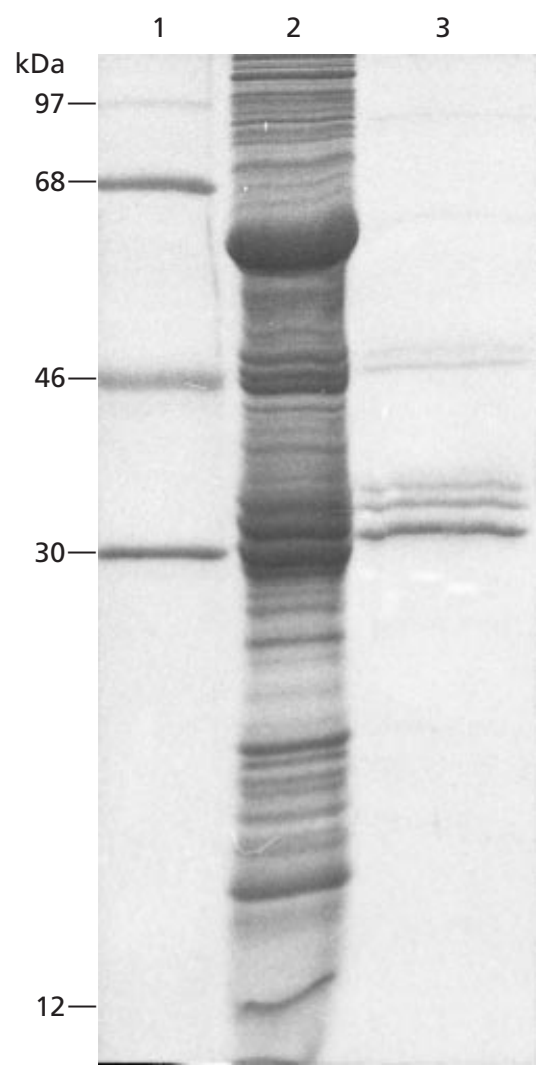

Fig. 6. Coomassie-brilliant-blue-stained SDS-PAGE gel $(12.5 \%$, $\mathrm{w} / \mathrm{v}$, acrylamide) showing $B$. bacilliformis (JB584) whole-cell lysate and BLP-associated proteins. Lanes: 1, molecular mass standards in $\mathrm{kDa} ; 2$, B. bacilliformis (JB584) whole-cell lysate showing the total protein profile; 3 , protein profile of purified BLPs showing three major bands of approximately 32, 34 and $36 \mathrm{kDa}$ and two minor bands of 47 and $49 \mathrm{kDa}$.

only SDS-treated BLPs yield a visible $14 \mathrm{kbp}$ band (Fig. 5, lane 6). These data suggest that the BLPs encapsidate their DNA inside a chloroform-resistant, SDS-sensitive protein coat, or capsid, much like a true bacteriophage.

BLP proteins. To investigate the polypeptide composition of the BLP coat, purified BLP protein profiles were examined. Three major bands of approximately 32, 34 and $36 \mathrm{kDa}$ and two minor bands of approximately 47 and $49 \mathrm{kDa}$ were observed on Coomassie-blue-stained SDS-PAGE gels (Fig. 6, lane 3) and are also found within the total cell lysate at high concentration (Fig. 6, lane 2). These major proteins have a similar molecular mass to those analysed for B. henselae BLPs (Anderson et al., 1994; Bowers et al., 1998). A corresponding immunoblot was also performed to determine if the BLP proteins are immunogenic in humans. Although detection by patient convalescent serum occurred, the level of detection was very faint, suggesting that the BLP proteins are modestly immunogenic (data not shown).

Packaging of host DNA into BLPs. A previous report showed that BLPs from B. henselae package host DNA in a 'near-random' fashion (Anderson et al., 1994). To 


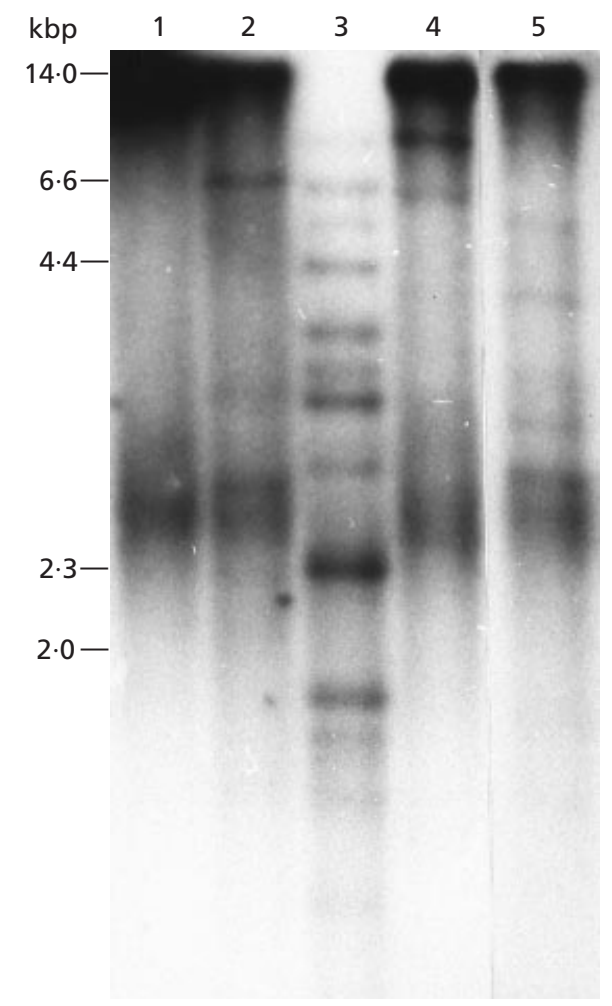

Fig. 7. Southern blot showing a RFLP analysis of BLP DNA using various restriction endonucleases. Electrophoretically separated BLP DNA fragments were transferred to nitrocellulose and probed using ${ }^{32} \mathrm{P}$-labelled BLP DNA. Molecular size standards are indicated on the left. Lanes: 1 , uncut BLP DNA migrating at $14 \mathrm{kbp} ; 2$, BamHI-digested BLP DNA; 3, Hindlll-digested BLP DNA; 4, EcoRI-digested BLP DNA; 5, Clal-digested BLP DNA.

assess the randomness of host DNA packaging by $B$. bacilliformis BLPs, both Southern blot and RFLP analyses were performed. When purified BLP DNA was digested separately with several restriction endonucleases (BamHI, HindIII, EcoRI and ClaI), distinct and repeatable banding patterns were observed on agarose gels (data not shown). In an effort to intensify the RFLP bands, Southern blots were done and probed with $\left[{ }^{32} \mathrm{P}\right] \mathrm{dCTP}$-labelled BLP DNA; a representative autoradiograph is shown in Fig. 7. Although the sum of the individual bands in each digest is greater than $14 \mathrm{kbp}$, a smear was never observed. These data suggest that the $14 \mathrm{kbp}$ BLP DNA is heterogeneous but not completely random in nature. Southern blot analysis using HindIII-cut B. bacilliformis DNA and ${ }^{32} \mathrm{P}$-labelled $B$. bacilliformis DNA as a probe showed multiple hybridization signals. In contrast, relatively few bands hybridized when ${ }^{32} \mathrm{P}$-labelled BLP DNA was used as a probe. Taken as a whole, these data suggest that packaging is far less random in B. bacilliformis BLPs than previously reported for $B$. henselae BLPs (Anderson et al., 1994).

To further analyse the specificity of packaging by $B$. bacilliformis BLPs, total genomic DNA preparations from B. bacilliformis (JB584) were Southern blotted and probed with various loci from the host chromosome, including the invasion associated locus B gene (ialB), the flagellin gene $(f l a)$, the gyrase B gene $(g y r B)$ and the 16S-23S rDNA intergenic spacer region. An additional probe consisting of the plasmid pBBR1MCS was used on KB484 to determine if BLPs package plasmid DNA. The resulting blots (not shown) showed that the BLPs package $i a l B$ and one of the 16S-23S rDNA intergenic spacers, but do not package fla or gyrB. As predicted, the shuttle plasmid pBBR1MCS was not packaged. These data further confirm that packaging is non-random.

\section{Transduction experiments}

To explore the potential role that BLPs play in horizontal gene transfer, site-directed mutants of Bartonella were generated to obtain a selectable, antibiotic-resistance marker that could be used to track the BLPmediated transfer of genes from one micro-organism to another. To accomplish this, we first needed to establish a site on the host chromosome that was not only packaged by BLPs, but also could be mutated without lethal effects on the bacterium. The 16S-23S ITS region was chosen for three reasons. First, three target loci exist on the B. bacilliformis chromosome. Second, inactivation of one of the rDNA operons would not likely be lethal since two remain. Finally, sequence conservation in this area exists across Bartonella species, facilitating future interspecies transduction experiments.

Development of $\operatorname{Kan}^{\mathrm{R}}$ B. bacilliformis mutants. An internal fragment of the 16S-23S rDNA operon was excised from pKRT3 (Minnick et al., 1994) with BamHI and SalI restriction enzymes. The same enzymes were used to create compatible ends on the Bartonella suicide vector pUB1 (Battisti \& Minnick, 1999). Ligation of the resulting fragments produced suicide vector pKB1, which was subsequently electroporated into JB584 and allowed to homologously recombine with the host chromosome. After $10 \mathrm{~d}$, DNA from two $\mathrm{Kan}^{\mathrm{R}} B$. bacilliformis mutants was analysed by agarose gel electrophoresis, PCR and Southern blotting. Both strains, KB584 and KB585 (Table 1), possessed the $14 \mathrm{kbp}$ BLP DNA (Fig. 8a, lanes 3-4, respectively). Southern blot analysis of the two mutants using ${ }^{32} \mathrm{P}-$ labelled $n p t I$ as a probe showed that KB585 contained the Kan-resistance gene in both the chromosome and the $14 \mathrm{kbp}$ BLP fragment (Fig. 8b, lane 4) whereas the other mutant, KB584, lacked BLP packaging of the locus (Fig. $8 \mathrm{~b}$, lane 3$)$. These data indicated that allelic exchange had occurred and a trackable marker, $n p t I$, was integrated into the B. bacilliformis chromosome. More importantly, BLPs from KB585 were packaging the mutagenized locus and its nested marker.

Coincubation of KB585 and KB484. Coincubation of KB585 and KB484 was performed to mimic a natural transduction event between two B. bacilliformis strains. This experiment led to five new $B$. bacilliformis strains, KB686 (A-E), which demonstrate both a $\mathrm{Kan}^{\mathrm{R}}$ and $\mathrm{Cam}^{\mathrm{R}}$ phenotype. However, PCR analysis (using both Kan and Cam primer sets) revealed the presence of only 
(a)

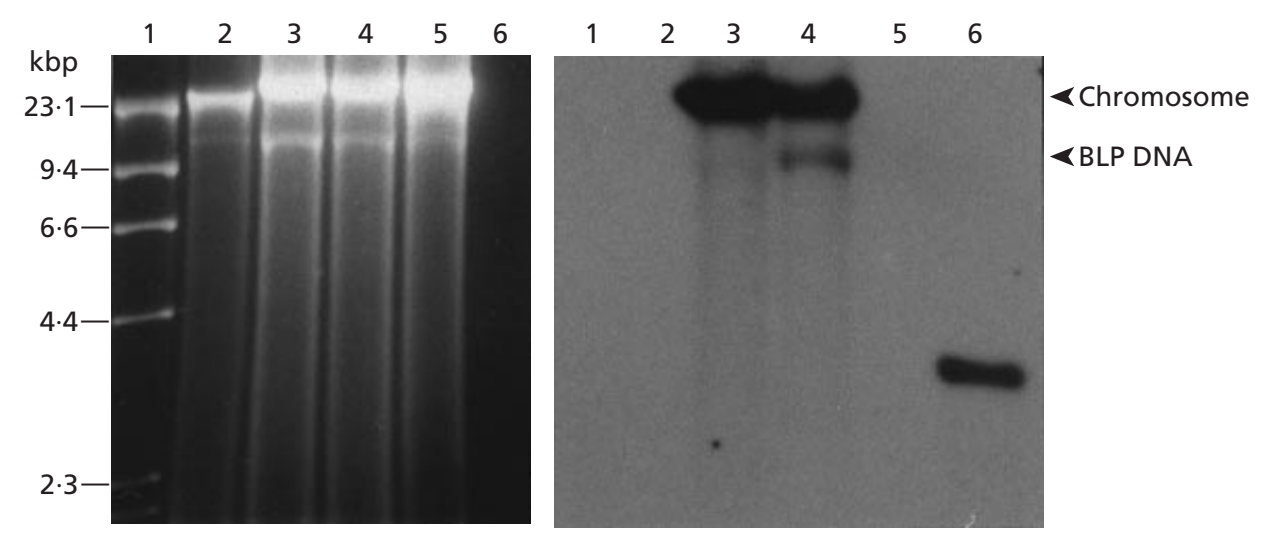

Fig. 8. DNA hybridization analysis showing BLP packaging of an integrated Kan-resistance gene. (a) Total DNA from $B$. bacilliformis showing both the chromosomal and BLP DNA, resolved on a $0.8 \%$ agarose gel. Lanes: $1, \lambda$-HindIII DNA as a molecular size standard; 2, total DNA from JB584; 3, total DNA from KB584 (mutant 1); 4, total DNA from KB585 (mutant 2); 5 , same as lane $2 ; 6$, linearized suicide plasmid used to generate the $B$. bacilliformis mutants and containing the Kanresistance gene (nptl). (b) Corresponding Southern blot of the gel in (a) probed with [32P]dCTP-labelled nptl. Note that while both mutants (KB584 and KB585) contain a chromosomal copy of nptl (lanes 3 and 4), only KB585 possesses BLPs that package the marker (lane 4).

the Kan-resistance gene, indicating that spontaneous antibiotic resistance to Cam produced the observed phenotype rather than transduction (data not shown).

Infection of JB584 or KB484 with purified BLPs from KB585. In an effort to rule out the possibility of conjugation or spontaneous Cam resistance, purified BLPs from strain KB585 were used in an attempt to transduce JB584 and KB484. Following an incubation period of approximately $28 \mathrm{~d}$, no colonies were observed on HIAB containing either Kan or a combination of Kan and Cam. A modification of these experiments was also done wherein purified BLPs were added to the JB584 or KB484 bacteria, and the mixtures were incubated in the recovery broth for $24 \mathrm{~h}$ prior to plating. However, these experiments met with failure.

Electroporation of JB584 or KB484 with purified BLP DNA. In the event that BLPs are non-infectious, the attachment and injection stage of the virus life cycle was circumvented by direct introduction of BLP DNA into $B$. bacilliformis by electroporation. High concentrations of KB585 BLP DNA (1-3 $\mu \mathrm{g})$ were electroporated into either JB584 or KB484, and the resulting electroporation mixture was plated on growth medium containing the appropriate antibiotic supplement(s). However, this technique also met with failure.

\section{DISCUSSION}

B. bacilliformis is a small, Gram-negative, intracellular parasite of human erythrocytes and endothelial cells. Although this haemotrophic bacterium is endemic to the Andes region of South America, 13 other species are found worldwide. Currently, five Bartonella species pose a significant health threat to humans and are the cause of a variety of emerging infectious diseases. Horizontal transfer of genes encoding virulence deter- minants may be a contributor to emergence. It is possible that transduction - an important means of gene transfer - may be facilitated by the BLPs found in association with many Bartonella species. BLPs have previously been described for B. henselae (Anderson et al., 1994; Bowers et al., 1998); however, little is known regarding the BLPs associated with B. bacilliformis. Thus the basis for this study was to provide a better understanding of the biology and genetics of the B. bacilliformis BLPs and to build a foundation on which to further explore the potential role they play in generalized transduction between and within Bartonella species.

Although BLP DNA was detected in a variety of Bartonella species, this study focuses on the basic characteristics of the BLPs from B. bacilliformis. We describe an extracellular particle associated with $B$. bacilliformis that is round to icosahedral in shape and approximately $80 \mathrm{~nm}$ in diameter. The particle is similar to those observed before (Anderson et al., 1994; Umemori et al., 1992); however, it is approximately twice the previously reported diameter, probably due to swelling during the uranyl acetate staining procedure (Ackermann et al., 1978). In contrast to observations made by Umemori et al. (1992), who reported tail structures in the B. bacilliformis phage, we observed no such structures in BLPs from any B. bacilliformis strain. Thus our results are more similar to those of Anderson et al. (1994), who found no tail structures in the $B$. henselae BLPs.

A $14 \mathrm{kbp}$ extrachromosomal DNA element was observed in total DNA from five Bartonella species. No $14 \mathrm{kbp}$ extrachromosomal DNA elements were seen in B. clarridgeiae, B. elizabethae or B. vinsonii DNA, suggesting that these Bartonella species are not infected or have been cured of BLPs. The $14 \mathrm{kbp}$ extrachromosomal DNA was not detectable in $\mathrm{CHCl}_{3}$-treated 
B. bacilliformis cells, suggesting that it is not retained as a naked element, but rather it is packaged into a protein head or capsid. Additionally, BLP DNA was not digested with DNase I until the BLPs were disrupted with SDS, providing further evidence that BLP DNA is being sequestered into a protective protein head. In this respect, BLPs appear to be similar to other generalized transducing bacteriophages.

To characterize the ends of the BLP DNA molecules, alkaline denaturation followed by rapid neutralization as well as two ligation techniques were employed. First, BLP DNA was shown to poorly renature following alkaline denaturation (Fig. 3). In contrast, a covalently closed linear plasmid (lp16) from Borrelia burgdorferi or a covalently closed circular plasmid rapidly renatured following the same treatments. These observations suggest that the BLP DNA ends are not covalently closed. Secondly, ligation of BLP DNA molecules to one another (or to themselves) only occurred under reaction conditions that favoured blunt-end ligation (Fig. 4). These data suggest that the BLP DNA termini consist of blunt ends, an observation that coincides with that of Anderson et al. (1994), who reported that B. henselae BLP DNA was able to ligate to BamHI linkers.

SDS-PAGE analysis of the BLP-associated proteins revealed three prominent bands with molecular masses of 32,34 and $36 \mathrm{kDa}$ and two minor bands with molecular masses of 47 and $49 \mathrm{kDa}$ (Fig. 6). BLPassociated proteins of similar mass were also observed in two different strains of $B$. henselae and one strain of B. bacilliformis by Anderson et al. (1994). Recently, one of the capsid genes that encodes a protein from $B$. henselae BLPs, termed Pap31, was isolated and sequenced (Bowers et al., 1998). Although it is not known if the $B$. bacilliformis BLP proteins are unique to the particle, the results suggest that the BLPs are composed of a distinct set of proteins that constitute a capsid. It is likely that synthesis of capsid proteins and a mechanism necessary for packaging the $14 \mathrm{kbp}$ fragments of host DNA emanates from genes contained within the host chromosome as previously hypothesized (Anderson et al., 1994).

Near-random packaging of $14 \mathrm{kbp}$ segments of host chromosome occurs in B. henselae BLPs (Anderson et al., 1994). However, RFLP and Southern blot analysis of BLP DNA from B. bacilliformis suggest that packaging by these BLPs is somewhat more selective. Although RFLP analysis revealed several BLP DNA fragments when subjected to various restriction endonucleases, the banding pattern was distinct and did not form a smear (Fig. 7), as observed in the heterogeneous mixture of chromosomal DNA packaged by the B. henselae BLPs (Anderson et al., 1994). Likewise, when B. bacilliformis chromosomal DNA was completely digested with HindIII, transferred to nitrocellulose and probed with $\left[{ }^{32} \mathrm{P}\right] \mathrm{dCTP}$-labelled chromosomal DNA, numerous bands were detected on the resulting autoradiograph creating a smear. In contrast, when B. bacilliformis chromosomal DNA was probed with $\left[{ }^{32} \mathrm{P}\right] \mathrm{dCTP}-$ labelled BLP DNA, a smearing effect was not observed; i.e. distinct banding was detected on the resulting autoradiograph. These data suggest that packaging of $B$. bacilliformis chromosomal DNA into BLPs is non-random and confined to certain loci on the host chromosome. Perhaps one of these fragments contains the 'ancestral' prophage genome.

To further investigate the non-random packaging event, specific loci from the $B$. bacilliformis chromosome were used to probe total genomic DNA preparations of $B$. bacilliformis to determine if virulence determinants, as well as other genes, were being packaged into the BLPs. In keeping with packaging data on $B$. henselae BLPs (Anderson et al., 1994), B. bacilliformis BLPs efficiently package at least one of the three rDNA operons in the $B$. bacilliformis chromosome. Furthermore, we discovered that at least one of the three 16S-23S ITS regions contained within the $B$. bacilliformis chromosome is packaged by BLPs from a mutagenized strain (KB585) (Fig. 8). Additional studies using DNA hybridization revealed that the gyrB gene and the fla gene were not packaged by the B. bacilliformis BLPs. However, the ialB gene, located in the middle of a known virulence gene cluster (Minnick et al., 1996), was shown to be packaged into the BLPs. Thus BLPs may contribute to horizontal gene transfer of virulence determinants via transduction; an activity that could facilitate the recent emergence of Bartonella species and bartonellosis.

Transduction has never been shown for any Bartonella species. Therefore, we completed a series of experiments designed to provide a foundation to investigate the potential role that BLPs play in generalized transduction. The first experiment was to insert an antibiotic-resistance marker into a BLP-packaged locus on the $B$. bacilliformis chromosome such that it could be used to track the transduction of antibiotic resistance to sensitive strains. However, several unsuccessful attempts were made to demonstrate transduction by $B$. bacilliformis BLPs. One possible explanation as to why we were unable to demonstrate transduction is superinfection immunity. This phenomenon occurs when a lysogen is exposed to a mature bacteriophage that is similar to the integrated prophage (Voyles, 1993), and has been thoroughly studied and documented for both $\lambda$ and T4 phage infection of E. coli (Yarmolinsky \& Sternberg, 1988; Voyles, 1993). For example, $\lambda$ phage blocks expression of incoming virus DNA by utilizing cytosolic repressor proteins. T4 phage prevents further infection by degrading incoming virus DNA. Because all B. bacilliformis strains examined contained BLPs, these micro-organisms may have a BLP-mediated mechanism that prevents subsequent BLP infection. For this reason, future transduction studies will be directed at producing an indicator strain of $B$. bacilliformis $\left(\mathrm{BLP}^{-}\right)$or implementing the use of other naturally $\mathrm{BLP}^{-}$Bartonella such as B. vinsonii, B. elizabethae or B. clarridgeiae. It is also possible that $B$. bacilliformis harbours nucleases designed for the degradation of linear DNA molecules, as previous attempts by our laboratory to mutagenize two loci with double-stranded or single-stranded linear DNA molecules were unsuccessful (Battisti et al., 1998; 
Battisti \& Minnick, 1999). Finally, the odds of a doublestranded crossover event would be low, especially considering the heterogeneity of the BLP DNA, i.e. only a minor fraction of the packaged BLP DNA would contain the $\operatorname{Kan}^{\mathrm{R}}:$ :ITS locus.

Horizontal gene transfer of virulence determinants has played a major role in the evolution of bacterial pathogens, and it is possible that this process may have contributed to the emergence of bartonellosis. Given the observation that BLPs can package at least one virulence gene, ialB, from the B. bacilliformis chromosome (Fig. 8 ), it is possible that they facilitate genetic exchange between Bartonella. We are currently investigating the role that BLPs play in mediating genetic exchange among members of the Bartonella genus as well as characterizing the packaging mechanism and the BLP genome in hopes of harnessing it as a potential tool in the genetic manipulation of B. bacilliformis.

\section{ACKNOWLEDGEMENTS}

We are grateful to Dr Burt Anderson and his group for their assistance and discussions concerning the purification of BLPs. Special thanks to Dr James Battisti for advice regarding sitedirected mutagenesis of Bartonella and transduction experiments. Special thanks to Christian Eggers and Pat Ball for technical assistance. We thank Joan Strange (The University of Montana Murdock Molecular Biology Facility) for synthesis of oligonucleotide primers. This work was supported in part by MONTS-NSF grant 292416 and NIH grant AI45534.

\section{REFERENCES}

Ackermann, H. W., Audurier, A., Berthiaume, L., Jones, L. A., Mayo, J. A. \& Vidaver, A. K. (1978). Guidelines for bacteriophage characterization. Adv Virus Res 23, 1-24.

Anderson, B., Goldsmith, C., Johnson, A., Padmalayam, I. \& Baumstark, B. (1994). Bacteriophage-like particle of Rochalimaea henselae. Mol Microbiol 13, 67-73.

Ausubel, F. M., Brent, R., Kingston, R. E., Moore, D. D., Seidman, J. G., Smith, J. A. \& Struhl, K. (1995). Current Protocols in Molecular Biology. New York: Wiley.

Barbour, A. G. \& Garon, C. F. (1987). Linear plasmids of the bacterium Borrelia burgdorferi have covalently closed ends. Science 237, 409-411.

Battisti, J. M. \& Minnick, M. F. (1999). Development of a system for site-directed mutagenesis of Bartonella bacilliformis. Appl Environ Microbiol 65, 3441-3448.

Battisti, J. M., Smitherman, L. S., Samuels, D. S. \& Minnick, M. F. (1998). Mutations in Bartonella bacilliformis gyrB confer resistance to Coumermycin $\mathrm{A}_{1}$. Antimicrob Agents Chemother 42, 2906-2913.

Benson, L. A., Kar, S., McLaughlin, G. \& Ihler, G. M. (1986). Entry of Bartonella bacilliformis into erythrocytes. Infect Immun 54, 347-353.

Birge, E. A. (1994). Bacterial and Bacteriophage Genetics, 3rd edn. New York: Springer.

Birnboim, H. C. \& Doly, J. (1979). A rapid alkaline extraction procedure for screening recombinant plasmid DNA. Nucleic Acids Res 7, 1513-1523.
Birtles, R. J., Harrison, T. G., Saunders, N. A. \& Molyneux, D. H. (1995). Proposals to unify the genera Grahamella and Bartonella, with descriptions of Bartonella talpae comb. nov., Bartonella peromysci comb. nov., and three new species, Bartonella grahamii sp. nov., Bartonella taylorii sp. nov., and Bartonella doshiae sp. nov. Int J Syst Bacteriol 45, 1-8.

Bowers, T. J., Sweger, D., Jue, D. \& Anderson, B. (1998). Isolation, sequencing and expression of the gene encoding a major protein from the bacteriophage associated with Bartonella henselae. Gene 206, 49-52.

Brenner, D. J., O'Connor, S. P., Hollis, D. G., Weaver, R. E. \& Steigerwalt, A. G. (1991). Molecular characterization and proposal of a neotype strain for Bartonella bacilliformis. J Clin Microbiol 29, 1299-1302.

Daly, J. S., Worthington, M. G., Brenner, D. J. \& 7 other authors (1993). Rochalimaea elizabethae sp. nov. isolated from a patient with endocarditis. J Clin Microbiol 31, 872-881.

Davis, R. W., Bostein, D. \& Roth, J. R. (1980). Advanced Bacterial Genetics. Cold Spring Harbor, NY: Cold Spring Harbor Laboratory.

Garcia-Caceres, U. \& Garcia, F. U. (1991). Bartonellosis. An immunodepressive disease and the life of Daniel Alcides Carrion. Am J Clin Pathol 95, S58-S66.

Garro, A. J. \& Marmur, J. (1970). Defective bacteriophages. J Cell Physiol 76, 253-264.

Hertig, M. (1942). Phlebotomus and Carrion's disease. Am J Trop Med 22, 1-76.

Humphrey, S. B., Stanton, T. B., Jensen, N. S. \& Zuerner, R. L. (1997). Purification and characterization of VSH-1, a generalized transducing bacteriophage of Serpulina hyodysenteriae. J Bacteriol 179, 323-329.

Hurtado, A., Musso, J. P. \& Merino, C. (1938). La anemia en la enfermadad de Carrion (verruga peruana). Ann Fac Med Lima 28, 154-168.

Kovach, M. E., Phillips, R. W., Elzer, P. H., Roop, R. M., II \& Peterson, K. M. (1994). pBBR1MCS: a broad-host-range cloning vector. BioTechniques 16, 801-802.

Kovach, M. E., Elzer, P. H., Hill, D. S., Robertson, G. T., Farris, M. A., Roop, R. M., II \& Peterson, K. M. (1995). Four new derivatives of the broad-host-range cloning vector pBBR1MCS, carrying different antibiotic-resistance cassettes. Gene 166, 175-176.

Kreier, J. P. \& Ristic, M. (1981). The biology of hemotrophic bacteria. Annu Rev Microbiol 35, 325-338.

Laemmli, U. K. (1970). Cleavage of structural proteins during the assembly of the head of bacteriophage T4. Nature 227, 680-685.

Lawson, P. A. \& Collins, M. D. (1996). Description of Bartonella clarridgeiae sp.nov. isolated from the cat of a patient with Bartonella henselae septicemia. Med Microbiol Lett 5, 64-73.

McGinnis-Hill, E., Raji, A., Valenzuela, M. S., Garcia, F. \& Hoover, R. (1992). Adhesion to and invasion of cultured human cells by Bartonella bacilliformis. Infect Immun 60, 4051-4058.

Minnick, M. F. (1997). Virulence determinants of Bartonella bacilliformis. In Rickettsial Infection and Immunity, pp. 197-211. Edited by B. Anderson, H. Friedman \& M. Bendinelli. New York: Plenum.

Minnick, M. F. \& Barbian, K. D. (1997). Identification of Bartonella using PCR; genus- and species-specific primer sets. J Microbiol Methods 31, 51-57.

Minnick, M. F., Heinzen, R. A., Frazier, M. E. \& Mallavia, L. P. (1990). Characterization and expression of the $c b b E^{\prime}$ gene of Coxiella burnetii. J Gen Microbiol 136, 1099-1107. 
Minnick, M. F., Strange, J. C. \& Williams, K. F. (1994). Characterization of the 16S-23S rRNA intergenic spacer of Bartonella bacilliformis. Gene 143, 149-150.

Minnick, M. F., Mitchell, S. J. \& McAllister, S. J. (1996). Cell entry and the pathogenesis of Bartonella infections. Trends Microbiol 4, 343-347.

Myers, W. F., Wisseman, C. L., Jr, Fiset, P., Oaks, E. V. \& Smith, J. F. (1979). Taxonomic relationship of vole agent to Rochalimaea quintana. Infect Immun 26, 976-983.

Regnery, R. L., Anderson, B. E., Clarridge, J. E., III, RodriguezBarradas, M. C., Jones, D. C. \& Carr, J. H. (1992). Characterization of a novel Rochalimaea species, $R$. henselae sp. nov., isolated from the blood of a febrile, human immunodeficiency viruspositive patient. J Clin Microbiol 30, 265-274.

Reynafarje, C. \& Ramos, J. (1961). The hemolytic anemia of human bartonellosis. Blood 17, 562-578.

Scherer, D. C., DeBuron-Connors, I. \& Minnick, M. F. (1993). Characterization of Bartonella bacilliformis flagella and effect of antiflagellin antibodies on invasion of human erythrocytes. Infect Immun 61, 4962-4971.
Southern, E. M. (1975). Detection of specific sequences among DNA fragments separated by gel electrophoresis. J Mol Biol 98, 503-517.

Towbin, H., Staehelin, T. \& Gordon, J. (1979). Electrophoretic transfer of proteins from polyacrylamide gels to nitrocellulose sheets: procedure and some applications. Proc Natl Acad Sci USA 76, 4350-4354.

Umemori, E., Sasaki, Y., Amano, K. \& Amano, Y. (1992). A phage in Bartonella bacilliformis. Microbiol Immunol 36, 731-736.

Voyles, B. A. (1993). The Biology of Viruses. Edited by R. J. Callanan. Boston: WCB/McGraw-Hill.

Weiss, E. \& Dasch, G. A. (1982). Differential characteristics of strains of Rochalimaea: Rochalimaea vinsonii sp. nov., the Canadian vole agent. Int J Syst Bacteriol 32, 305-314.

Yarmolinsky, M. B. \& Sternberg, N. (1988). Bacteriophage P1. In The Bacteriophages, pp. 291-438. Edited by R. Calendar. New York: Plenum.

Received 28 July 1999; revised 2 November 1999; accepted 6 December 1999. 